\title{
Author Correction: Knowledge graph prediction of unknown adverse drug reactions and validation in electronic health records
}

\section{Daniel M. Bean ${ }^{1}$, Honghan Wu ${ }^{1}$, Ehtesham Iqbal ${ }^{1}$, Olubanke Dzahini ${ }^{2,3}$, Zina M. Ibrahim ${ }^{1,5}$, Matthew Broadbent ${ }^{2}$, Robert Stewart ${ }^{2,4}$ \& Richard J. B. Dobson (10) ${ }^{1,5}$}

Correction to: Scientific Reports https://doi.org/10.1038/s41598-017-16674-x, published online 27 November 2017

Ehtesham Iqbal and Zina M Ibrahim were omitted from the author list in the original version of this Article. This has been corrected in the PDF and HTML versions of the Article, and the accompanying Supplementary Information.

The Author Contributions section now reads:

D.B., H.W. and R.J.B.D. designed the study. O.D. advised on validation. H.W. and E.I. processed EHR data. D.B. designed the prediction algorithm, performed analysis and prepared the manuscript. R.J.B.D., Z.M.I., M.B. and R.S. supervised the project. All authors reviewed the manuscript.

In addition, the original version of this Article contained an error in Reference 16.

"Iqbal, E. et al. Identification of Adverse Drug Events from Free Text Electronic Patient Records and Information in a Large Mental Health Case Register. PLoS One 10, 1-14 (2015).”

now reads:

"Iqbal, E. et al. ADEPt, a semantically-enriched pipeline for extracting adverse drug events from free-text electronic health records. PLoS One 12, 1-16 (2017)." 
(i) Open Access This article is licensed under a Creative Commons Attribution 4.0 International License, which permits use, sharing, adaptation, distribution and reproduction in any medium or format, as long as you give appropriate credit to the original author(s) and the source, provide a link to the Creative Commons license, and indicate if changes were made. The images or other third party material in this article are included in the article's Creative Commons license, unless indicated otherwise in a credit line to the material. If material is not included in the article's Creative Commons license and your intended use is not permitted by statutory regulation or exceeds the permitted use, you will need to obtain permission directly from the copyright holder. To view a copy of this license, visit http://creativecommons.org/licenses/by/4.0/.

(C) The Author(s) 2018 